\title{
Exploring the Potentiality of Family Resources on Basic Household Sanitation Management in Dense Settlements of Binjai in North Sumatera Province of Indonesia
}

\author{
Evi Naria*(iD, Heru Santoso(D), Kintoko Rochadi(D), Nurmaini Nurmaini(D) \\ Department of Environmental Health, Faculty of Public Health, Universitas Sumatera Utara, Medan, Indonesia
}

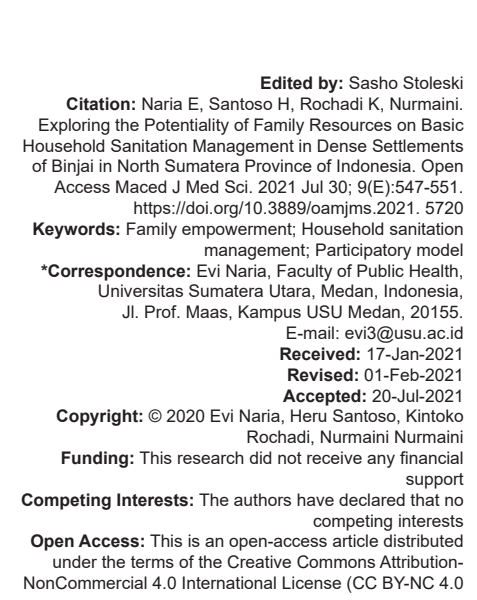

Introduction

Poor sanitation has been a challenging problem in Indonesia. According to Virencia [1], 87.8\% of households in Indonesia have access to safe drinking water sources, and $74.6 \%$ of households have access to proper sanitation. Meanwhile, the remaining $25.4 \%$ do not have access to proper sanitation. However, WHO [2] states that clean water and proper sanitation can reduce $95 \%$ of the risks of diarrhea.

Binjai is a densely populated region in North Sumatera Province, Indonesia. A study conducted by Naria and Nurmaini [3] investigating the household sanitation practices in the region found that $99.5 \%$ of households owned latrines, but feces around the sanitation facilities were found in $81.2 \%$ of the houses. Moreover, $54.5 \%$ of the households used the latrine room or toilet for multiple functions including washing the dishes. Most importantly, although $96.5 \%$ of the households had an access to clean water, dirty, and slippery toilet floors were still found in $39.1 \%$ of houses. Meanwhile, unavailable cleaning supplies and equipment were found in $15.3 \%$ of the houses. Other significant findings are $53.0 \%$ of households washed their hands before preparing and eating food, $70.03 \%$ of households washed their hands after defecating, 40.1\% of the household had unclean drinking water storage containers, $46.4 \%$ of the household had unclean food storage containers, and $58.4 \%$ of the households had filthy kitchens.

Several types of relevant research on sanitation management generally focused on the study of human resources and sanitation officers, sanitation policy, and sanitation costs. The different types of research proposed that sanitation management can be improved by community participation and adequate sanitation cost and facilities [4], [5], [6], [7]. The research involved the community to study sanitation, but the main implementation unit was centered on households.

Previously, family empowerment has been studied and implemented on disease management 
for families. However, the family empowerment to improve household sanitation has not been optimally implemented Martono and Satino [8] found that the community nursing care model impacts the variables of health cadre the community nursing care model impacts the variables case management for families. However, the family empowerment to improve household sanitation behavior is family empowerment. Family empowerment and control from the head of the family can improve the family sanitation behavior.

The implementation of the Family-centered Nursing Model on family health care tasks shows significant improvement in the ability of families to recognize acute respiratory infections symptoms $(p=0.00)$, decision-making $(p=0.00)$, and environment modification $(p=0.001)$. The model has increased the family independence in carrying out family health care task [9].

Various types of research on family empowerment conducted in the health care sectors show that there has been an improvement in the abilities to recognize the family health problems, to take better health actions, to modify the environment, and to manage the family health independently [9], [10].

Unfortunately, the families who have implemented the sanitation have not received the attention and rewards from the community, health department, and other related agencies. The results of the previous survey found that mosthousewives admitted that they cannot do the whole household sanitation tasks since they are also responsible for the other household chores. An analysis of family resources thus is highly required for the synergy between aspirations and resources in implementing household sanitation as a spearhead of community-based sanitation programs. The family resource is a considerable variable that has not been studied extensively to improve household sanitation management.

\section{Methods}

The research applied a qualitative method. The research was conducted in a densely populated area in Binjai, North Sumatera Province, Indonesia. It involved 10 respondents comprising of the housewives and the stakeholders of sanitation management. The data were collected by applying several data collection techniques including in-depth interviews, observation, and documentation. Triangulation was used to check the data validation through cross verification from the data sources. The data then were analyzed descriptively to find the phenomena in sanitation management based on family resources.

\section{Results}

\section{Family resources for household sanitation management}

The results of in-depth interviews with stakeholders and housewives about household sanitation management found that family is the human resource in a household. When each member of the family plays their respective roles in family management, prosperity which is the main goal of the family will be achieved. The role of each member of a family in household management builds unity for the family because everything is done based on family cooperation.

The information collected from the respondents draws several themes that can improve the participation and support of the entire family members in basic household sanitation management (Table 1).

\section{The facilities and management of household waste}

The temporary dump sites located around the community's houses are commonly provided by the government. Housewives have had the awareness to collect the garbage into the temporary dump sites in their neighborhood. The people themselves carry the garbage from their house to be gathered in the temporary dump sites. The reasons for proper waste management are to avoid the garbage become the nesting place of flies and to make sure that the garbage is not scattered around their houses. The garbage is collected in a plastic bag to make it easier to carry and put into the dump sites at once.

Toilet can be found in the houses, but most of the houses do not have septic tanks because of having insufficient land. The waste from the toilet is streamed to the public stream and flows to the river. The toilet in the house has been used by all the family members although the toilet structure is physically very basic. The condition of some toilet still has a slippery floor and the toilet has a bad smell.

The household waste generated from the activities in the bathroom and kitchen, such as the waste of washing dishes, is streamed to the public ditch. Public ditch as the stream of waste disposal flows to Mencirim River (a river located around the dense area). Today, the water of the Mencirim River is still used by the people around the river for showering and washing.

\section{Discussion}

\section{Family resources for household sanitation management}

In general, the mother is the main agent of sanitation management in households. Mothers 
recognize sanitation as tasks related to latrines, waste management, water management, and household hygiene. The purpose of sanitation management which mother has been carried out is basically for cleanliness and tidiness of the house.

The sanitation tasks in households are done every day. Mothers spend an average of $2 \mathrm{~h}$ a day to carry out sanitation tasks. It is regularly started in the morning. Housewives do several chores for maintaining the overall cleanliness of the house including cleaning the toilet and bathroom. These are definitely not enormous tasks, but if mothers do the tasks herself every day, they will feel tired and they occasionally will be lazy to do the cleanliness tasks.

Family members who live in a house are the human resource that can play a role in household management, including in sanitation management. There has no clear description of the role and responsibility of each family member in the household sanitation management. Thus, the sanitation tasks are mostly carried out by mother.

The participation of all family members can support the sanitation management in a household. Nevertheless, most informants admitted that the other family members merely help mother in certain tasks such as repairing things and other heavy sanitation tasks. Support from other family members, however, does not occur spontaneously. There is a tendency that father and children help mother only when mother asks for help. Commonly, the role of daughters in household management is higher than sons.

Household sanitation management which involves all family members occurs incidentally. Sanitation management has been carried out without a clear job description for each family member. Therefore, the participation of family members does not occur voluntarily, but it depends on the requests from mother. There is no clear deal of who will do a certain task such as sweeping the floor, taking out the trash, and cleaning the bathroom and toilet. Each family member does not have a responsibility to do certain sanitation tasks.

The human resource of a family consists of father, mother, and children. These members should participate in household sanitation management. Empathy among the family members is reflected by their involvement in carrying out the sanitation tasks. They do not help each other spontaneously. The role of each family member is not visible. Mother usually has a dominant household workload. Mother often complains about the dominant household tasks because they are tired. They admitted that they cannot do the whole tasks individually. They also frequently become lazy to the sanitation tasks. Some families have carried out the sanitation management tasks by family cooperation, but no one is responsible for maintaining sanitation facilities at home. Sanitation maintenance by other family members is not carried out only routinely, but only for certain conditions.
Besides the human resources, the family also consists of material resources. Economic capability is one of the material resources, which is highly important to build a successful family. Economic problems can obstruct the improvement of the family, including in managing basic sanitation in households, especially for preparing basic sanitation facilities.

The participation of the community can encourage families in improving sanitation management. Households expect guidance from others who completely understand sanitation. The community can also become their partners in discussing the implementation of basic sanitation in the household. This can positively impact the improvement of the household sanitation quality. Moreover, housewives also expect rewards as appreciation and recognition for the sanitation management that they have done every day.

To support the implementation of proper sanitation in households, the government should provide communal sanitation facilities. Supporting facilities can be utilized by households to achieve a better sanitation practice such as trash can shelters and qualified household sewer. The households and the officers from the related department should be involved in maintaining the facilities.

Information and knowledge about sanitation also should be provided to every household to support the improvement of household sanitation management. Guidance program and sanitation socialization have been held by the Health Department, Community Health Centers (Puskesmas), the Environmental Agency, and the Public Works Service in the Sanitation sector. In general, the target of the socialization is mothers, not whole family members as the human resource in a household.

\section{Basic sanitation in household}

Sanitation facility is the facility that a family has in their household for the need of sanitation activities. The basic sanitation facilities include the facilities of clean water and drinking water supply, facility of waste disposal in a household, the facility of toilet in a family, and facility of households' waste disposal. The availability of facilities must be followed by maintenance so that the benefit of safety and convenience could be achieved. Sanitation facility is the material resources of households.

The sources of clean water of households come from boreholes. In quantity, the households have already had an adequate clean water supply for daily needs, such as for showering and washing clothes. Adequate clean water for family needs is seen from the aspects of quantity, quality, and continuity. In the aspect of quantity, the amount of water is already available for families. However, based on the aspect of quality, the 
water has not met the health requirements. The physical quality is the first quality which can be visibly observed to see the clarity of the water. The aspect of continuity of water supply has been fulfilled. Clean water is stored in a container to ensure the water is available when it is needed. The need for drinking water is fulfilled by buying drinking water in a water depot.

\section{The facilities and management of household waste}

The family has the potential capability to manage sanitation in the household. Several strengths which a family has are: (1) Human resource consisting of father, mother, and children, (2) father and children willingly to help mother to do sanitation management in household, (3) family attempting to improve the sanitation by following several ways such as joining the sanitation activities held by community in their neighborhood, having environmental awareness, and putting the garbage into provided dump sites around their house, and (4) sanitation facilities provided such as waste disposal stream and garbage can at home. The strengths that a family has are in the forms of human resources and sanitation facilities. These strengths can be a modal to do a positive change in the family to improve the quality of sanitation.

Basic sanitation facilities owned by families in densely populated areas frequently do not meet health requirements, in which waste water disposal still uses open drains. In addition, household waste is badly managed. This condition, according to Nurmaini and Sudaryati [11], will cause an unpleasant smell around the house. In addition, it will invite disease vectors, such as flies, cockroaches, and mosquitoes, thereby facilitating the spread of disease since most families also have opened sewers and trash can.

The study of improving sanitation in community conducted by Almazan [12] shows that there was a sanitation change after the intervention was given such as the existence of garbage can ( $p=0.000)$, defecating in the toilet $(p=0.000)$, and washing hands after defecating $(p=0.000)$. Almazan [13] states that the family empowerment is affected by characteristic around 0.13 , and the empowerment intervention affects around 0.14 . The next step, family empowerment will affect the level of family prosperity around 0.47 , so it could be claimed that the more empowered a family is, the more the family prosperity will be achieved.

The involvement of stakeholders also gives a chance in improving sanitation management in households. Several roles of stakeholders are: (1) Delivering various information about sanitation performed by the institutions related to sanitation through socialization and counseling, (2) supporting the family and the community to improve the sanitation quality in the households, (3) increasing the involvement and role of the public figures in sanitation activity already done all this time, and (4) preparing a temporary dump sites around the community's houses.

The situation and condition of a family are a foundation to find the family togetherness and participation in managing the household sanitation. Household has already had strength in resources that can be properly managed. Housewives who are a weighted point of sanitation management for all this time can share the role to the other family members so that the family participation in managing sanitation can be more optimal. Sharing task in the family also gives a chance to all family members to participate.

Ife and Frank [14] states that someone will participate in an activity if there is a condition that encourages them to participate. The condition includes: (1) A perception that the activity is important, (2) their involvement can positively change their life, (3) the participation is recognized and appreciated, (4) the given participation is supported, and (5) its structure and process did not exile.

The family resource is the basis for family empowerment in managing basic sanitation in the household. Some optimized factors in managing sanitation are:

1. Family resources, which include the role and responsibility of each family member, family participation in sanitation tasks, financial capability, and sanitation facilities

Table 1: The matrix of basic sanitation management themes for households in Binjai

\begin{tabular}{|c|c|c|}
\hline Category & Sub-themes & Themes \\
\hline $\begin{array}{l}\text { The household human resources } \\
\text { including all of the family } \\
\text { members in the household } \\
\text { No clear role and responsibility of } \\
\text { each family member in household } \\
\text { sanitation management } \\
\text { (the household sanitation tasks } \\
\text { are mostly carried out by mother, } \\
\text { meanwhile he other family } \\
\text { members only help only when } \\
\text { mother asks for help) }\end{array}$ & $\begin{array}{l}\text { The role and the } \\
\text { responsibility of each family } \\
\text { member }\end{array}$ & $\begin{array}{l}\text { The family } \\
\text { resources }\end{array}$ \\
\hline $\begin{array}{l}\text { The housewives a decision } \\
\text { to follow the instructions of } \\
\text { sanitation management }\end{array}$ & $\begin{array}{l}\text { The participation of all family } \\
\text { members in household } \\
\text { sanitation management }\end{array}$ & \\
\hline $\begin{array}{l}\text { The financial incapability of the } \\
\text { households to pay the sanitation } \\
\text { costs }\end{array}$ & $\begin{array}{l}\text { The economic capability of } \\
\text { the family }\end{array}$ & \\
\hline $\begin{array}{l}\text { The existence and maintenance } \\
\text { of sanitation facilities }\end{array}$ & $\begin{array}{l}\text { The sanitation facilities for } \\
\text { households }\end{array}$ & \\
\hline $\begin{array}{l}\text { The competence of the agencies } \\
\text { to provide socialization about } \\
\text { household sanitation to the } \\
\text { community }\end{array}$ & $\begin{array}{l}\text { The involvement of related } \\
\text { departments in providing } \\
\text { information about household } \\
\text { basic sanitation }\end{array}$ & $\begin{array}{l}\text { The sources } \\
\text { of sanitation } \\
\text { information and } \\
\text { knowledge }\end{array}$ \\
\hline $\begin{array}{l}\text { Support and direct involvement in } \\
\text { sanitation tasks }\end{array}$ & $\begin{array}{l}\text { The involvement of the } \\
\text { community }\end{array}$ & $\begin{array}{l}\text { Support } \\
\text { in family }\end{array}$ \\
\hline $\begin{array}{l}\text { The desire to get guidance in } \\
\text { improving the sanitation quality }\end{array}$ & Family encouragement & encouragement \\
\hline $\begin{array}{l}\text { The desire to get a reward for the } \\
\text { households who practice a proper } \\
\text { sanitation management }\end{array}$ & Reward & \\
\hline $\begin{array}{l}\text { Various facilities provided by } \\
\text { the government to support } \\
\text { the household sanitation } \\
\text { management }\end{array}$ & $\begin{array}{l}\text { Sanitation facilities provided } \\
\text { by the government }\end{array}$ & $\begin{array}{l}\text { Supporting } \\
\text { facilities for } \\
\text { household } \\
\text { sanitation }\end{array}$ \\
\hline $\begin{array}{l}\text { The community facilities for } \\
\text { household sanitation support } \\
\text { the household sanitation } \\
\text { management }\end{array}$ & $\begin{array}{l}\text { The involvement of } \\
\text { household in maintaining } \\
\text { the sanitation facilities }\end{array}$ & \\
\hline
\end{tabular}


2. Source of information and knowledge, which comes from related institutions such as the health department

3. Motivations in family empowerment, which include the involvement of public figures, guidance, and appreciation or rewards

4. Supporting sanitation facilities of households provided by government in which the maintenance of the facilities could involve the community and sanitation officers.

Hatu [15] states that maintenance puts humans as the subject into themselves. Humans are given a process to enable themselves to be empowered, supported, and motivated to gain a capability in determining their life choices. There are the ability to fulfill their needs in some aspects such as physics, sociability, confidence, economy, being able to convey aspiration, participation in social lives, and (5) being independent in their own lives. Sofyan et al. [16] states that the important factors in managing sanitation by community in slums are sanitation costs and community selves to family empowerment, therefore is significantly required for better household management, specifically for the people living in the dense settlement areas.

\section{Conclusion}

This study concludes that mother is the human resource in a family who plays the key role in managing sanitation, meanwhile father and children help mother incidentally. Material resources such as sanitation facilities are available, yet the maintenance of the facilities has not been done well because the mother cannot do all tasks by herself. The household sanitation management can be improved by optimizing the role of resources in the family, utilizing the source of information and knowledge, giving motivations in family empowerment, and the providing supporting sanitation facilities.

\section{Acknowledgment}

The authors would like to give highest appreciation for the support and information given by all participants and informants involved in this research, especially for the field assisting team collecting the data from the community in Binjai City, North Sumatera Province, Indonesia.

\section{References}

1. Virencia K. Menuju RPJMN 2020, Sanitasi and Air Minum Prakondisi Wajib Bagi Permukiman Layak. Jakarta: National Housing Water and Sanitation Information Services; 2020. p. 1.

2. World Health Organization. WHO Estimates of the Global Burden of Foodborne Diseases: Executive Summary. Geneva: World Health Organization; 2015. p. 257.

3. Naria E, Nurmaini N. Environmental-based Diseases Prevention by Improving Sanitation Quality in Binjai. Medan: Research Report Universitas Sumatera Utara; 2018.

4. Turnip V, Ali M.M. Partisipasi Masyarakat Dalam Pembangunan Sanitasi Perkotaan Di Kelurahan Rowosari Kecamatan Tembalang Kota Semarang. Teknik Perencanaa Wilayah Kota. 2015;4(2):319-31.

5. Sugiharti S. Analisis Pelaksanaan Program Sanitasi Total Berbasis Masyarakat Pilar Pertama (Stop Babs) Sebagai Upaya Meningkatkan Cakupan Desa Odf (Open Defecation Free) Oleh Petugas Puskesmas di Kabupaten Temanggung. Semarang: Universitas Diponegoro Semarang; 2016. p. 494. https://doi. org/10.20473/jaki.v4i2.2016.107-116

6. Abdat M, Kresno S. Studi kualitatif tentang pelaksanaan program perilaku hidup bersih dan sehat (phbs) tatanan rumah tangga. Cakradonya Dent J. 2017;1(9):62-72. https://doi.org/10.24815/ cdj.v9i1.9880

7. Venkataramanan $\mathrm{V}$, Crocker J, Karon A, Bartram J. Community-led total sanitation: A mixed-methods systematic review of evidence and its quality. Environ Health Perspect. 2108;126(2):026001. https://doi.org/10.1289/ehp1965 PMid:29398655

8. Martono M, Satino S. Model of community health nursing care to accelerate MDGS on health sanitation behavior sector. J Ners. 2015;10(2):301-7. https://doi.org/10.20473/jn.v10i22015.301-307

9. Erlinda V. Penerapan model family-centered nursing terhadap pelaksanaan tugas kesehatan keluarga dalam pencegahan ISPA pada Balita di Wilayah Kerja Puskesmas Simpang Tiga Kabupaten Aceh Besar. J Kedokt Yarsi. 2015;23(2):165-86. https://doi.org/10.30867/action.v2i1.35

10. Ratnasari TB, Prasinta AD. Effect family empowerment in increasing family koping with diabetes mellitus type 2 in the krajan and krajan hamlet, Glagahwerovillage, Panti districts, jember regency. Indones J Health Sci. 2018;141-4. https://doi. org/10.32528/ijhs.v0i0.1537

11. Nurmaini N, Sudaryati E. Relationship between sanitation hygiene and health care with healthy family security of the family of smokers at Berastagi subdistrict. Open Access Maced J Med Sci. 2019;7(17):2874-8. https://doi.org/10.3889/oamjms.2019.419 PMid:31844452

12. Almazan JU. Participatory hygiene and sanitation transformation (phast) in a remote and isolated community in Samar Province, Philippines. Curr Health Sci J. 2014;40(4):233-43. PMid:26793319

13. Sjafari A. Pemberdayaan keluarga miskin melalui pendekatan kelompok. J Adm Publik. 2010;1(2):167-78.

14. Ife T, Frank J. Community Development. Yogyakarta: Pustaka Pelajar; 2016.

15. Hatu RA. Pemberdayaan dan pendampingan sosial dalam masyarakat (suatu kajian teortis). J Inovasi. 2010;7(4):240-54.

16. Sofyan MH, Soewondo P, Kunaefi TD. Faktor-faktor Penting Pengelolaan Sanitasi Oleh Masyarakat di Kawasan Kumuh Perkotaan Bandung Raya, 2014. Prosiding: Seminar Nasional Teknik Sumber Daya Air. Jakarta: Universitas Katholik Admajaya; 2014. https://doi.org/10.5614/j.tl.2016.22.1.9 